\title{
MIGRACJE WEWNĘTRZNE I ZAGRANICZNE W AGLOMERACJI POZNAŃSKIEJ W LATACH 1990-2011
}

ABSTRACT. Walaszek Marzena, Migracje wewnętrzne i zagraniczne w aglomeracji poznańskiej w latach 1990-2011 [Internal and international migration in the Poznań agglomeration in the years 1990-2011] edited by J. Kubera, Ł. Skoczylas - „Człowiek i Społeczeństwo”, vol. XXXVII, Poznań 2014, pp. 75-90, Adam Mickiewicz University Press. ISBN 978-83-232-2764-9. ISSN 0239-3271.

Metropolitan areas in Poland are places of intense social, economic and spatial growth. The socioeconomic development of metropolitan areas is closely linked with the collective needs of the local society. These needs change over time and depend on the spatial scale of population movements, changes in the demographic structure and lifestyle. In the article, directions and reasons for migrations into the Poznan agglomeration in 1990-2011 were examined. The conclusion is that intensive development of housing affected the move to suburban areas.

Marzena Walaszek, Uniwersytet im. Adama Mickiewicza w Poznaniu, Centrum Badań Metropolitalnych UAM, ul. Dzięgielowa 27, 61-680 Poznań. Autorka jest stypendystką Fundacji Uniwersytetu im. Adama Mickiewicza w Poznaniu na rok 2013/2014.

\section{WSTĘP}

Migracje ludności są jednym z głównych elementów badań demograficznych. W centrum badań nad migracjami leżą: przyczyny, kierunki oraz natężenie migracji. Badania te są cennym źródłem wiedzy o społeczeństwie. Wnikliwe analizy dotyczące ruchu ludności pozwalają na ocenę głównych motywacji i kierunków migracji, a przez to pośrednio na ocenę stanu zamożności migrantów (występowanie tzw. migracji zarobkowych) oraz satysfakcji z życia w dotychczasowym miejscu.

Ze względu na kryterium przestrzenne wyróżnia się migracje wewnętrzne (związane z przekraczaniem granic administracyjnych wewnątrz jednego kraju - wojewódzkie, powiatowe, gminne) oraz migracje zewnętrzne (tzw. zagraniczne, związane z przekraczaniem granic państwowych). 
W obu przypadkach migranci pokonują różne odległości, ale ich motywacje pozostają bardzo podobne, a najważniejszą z nich jest poprawa warunków życiowych (najczęściej ekonomicznych i mieszkaniowych).

Przystąpienie Polski do Unii Europejskiej w 2004 r. oraz do układu z Schengen w 2007 r. spowodowało wzrost migracji zagranicznych Polaków. Przez ostatnich kilka lat zachodzące na dużą skalę migracje zagraniczne Polaków stanowiły ważny element badań socjologicznych i demograficznych. Wokół migracji zagranicznych Polaków koncentrowały się również ożywione dyskusje i debaty polityczne, których celem było zatrzymanie odpływu młodych i wykształconych obywateli naszego kraju poza jego granice (tzw. drenaż mózgów).

W ostatnich latach w Polsce nastąpił wzrost zainteresowania obszarami wielkomiejskimi, ich problemami i potencjałami rozwoju. Niewątpliwie proces ten wzmocniony został przez politykę spójności Unii Europejskiej, która w Strategii Europa 2020 podkreśla strategiczne znaczenie miast dla przyszłego rozwoju Europy, a w najbliższej perspektywie finansowej 2014-2020 deklaruje wsparcie dodatkowymi funduszami tzw. zintegrowanych inwestycji terytorialnych. W największych aglomeracjach polskich w ostatnich latach dochodzi do zawiązywania i zacieśniania współpracy aglomeracyjnej, której celem jest między innymi wypracowanie wspólnej polityki w wielu dziedzinach zarządzania usługami publicznymi. Dynamicznie rowijające się ponad granicami administracyjnymi aglomeracje miejskie stały się także obiektem badań naukowych. Powszechnie uważa się, że aglomeracje miejskie są motorami rozwoju społeczno-gospodarczego regionów. W wyniku badań, prowadzonych między innymi na potrzeby opracowania Krajowej Przestrzennej Koncepcji Zagospodarowania Kraju („Miejskie obszary funkcjonalne"), można sformułować tezę, iż na obszarach polskich aglomeracji dochodzi do intensywnego rozwoju społeczno-gospodarczego, którego widocznym przejawem jest na przykład „wylewanie się" zabudowy i działalności gospodarczej poza granice administracyjne miast (tzw. suburbanizacja) oraz migracje mieszkańców miast centralnych do ich stref podmiejskich. Migracje mieszkańców dużych miast są zjawiskiem, które powszechnie uważa się za skutek globalizacji i suburbanizacji (Kaczmarek 2008). Etap suburbanizacji jest, obok urbanizacji i dezurbanizacji, jednym z etapów rozwoju miasta (Paelinck, Klaassen 1979).

W aglomeracji poznańskiej szczególnie intensywny proces suburbanizacji rozpoczął się po roku 2000. Wzrost zamożności mieszkańców, dynamiczne procesy gospodarcze i intensywny rozwój budownictwa mieszkaniowego wpłynęły na migracje mieszkańców Poznania do jego strefy podmiejskiej. Pragnienie posiadania własnego domu z ogródkiem, chęć ucieczki od wiel- 
komiejskiego zgiełku, potrzeba bycia blisko natury to najbardziej typowe motywacje mieszkańców osiedlających się poza granicami miasta.

Napływ ludności do jakiegoś miejsca powinien być zawsze rozpatrywany jako równoczesny odpływ ludności z innego miejsca (tzw. teoria czynników wypychających i przyciągających - push and pull factors). Zarówno napływ, jak i odpływ wędrówkowy ludności mają swoje pozytywne oraz negatywne konsekwencje. $W$ przypadku migracji wewnętrznych zachodzących na obszarze aglomeracji poznańskiej, będących głównie skutkiem suburbanizacji, dychotomia tego procesu oznacza odpływ ludności z miasta Poznania (rdzenia aglomeracji) oraz napływ ludności na tereny podmiejskie. W przypadku niewielkich ruchów wędrówkowych ludności ich natężenie i skala nie wywierają większego wpływu na funkcjonowanie społeczeństwa i przestrzeni, w której migracje te zachodzą. W przypadku dużego natężenia migracji zachodzących $\mathrm{w}$ krótkim czasie można oczekiwać obniżenia się standardu życia, a nawet konfliktów społecznych, będących skutkiem problemów wynikających ze zwiększonego zatłoczenia dróg, szkół czy przychodni zdrowia.

Migracje to, obok ruchu naturalnego, główny komponent wpływający na stan i rozmieszczenie ludności w aglomeracji poznańskiej. Oba czynniki rozwoju powinny stanowić ważny element aktualnych oraz przyszłych badań nad aglomeracją poznańską. Ich celem należy uczynić również ocenę potencjałów konkurencyjnych aglomeracji, w tym kapitału ludzkiego i społecznego, jako elementów wpływających na zrównoważony rozwój społeczno-gospodarczy aglomeracji.

\section{CEL I ZAKRES BADAŃ ORAZ ŹRÓDŁA DANYCH}

Celem badań była identyfikacja kierunków i przyczyn migracji zachodzących na obszarze aglomeracji poznańskiej w latach 1990-2011.

W artykule dokonano przeglądu dynamiki migracji zagranicznych, które ukazują proces migracji mieszkańców aglomeracji poznańskiej poza granice kraju oraz liczbę obcokrajowców przyjeżdżających na stałe do aglomeracji. Migracje wewnętrzne $w$ aglomeracji poznańskiej przedstawione zostały na tle rozwoju rynku mieszkaniowego i procesu suburbanizacji, które są głównymi stymulatorami przeprowadzek mieszkańców poza Poznań.

Zakres przestrzenny badań obejmuje obszar aglomeracji poznańskiej, na który składa się: miasto centralne Poznań i 17 gmin miejskich, wiejskich i miejsko-wiejskich powiatu poznańskiego. Zakres przedmiotowy badań stanowią migracje wewnętrzne i zagraniczne. Zakres czasowy badań doty- 
czy lat 1990-2011, a więc okresu transformacji ustrojowej oraz dynamicznego rozwoju strefy podmiejskiej po roku 2000.

W badaniach wykorzystano zarówno wtórne, jak i pierwotne źródła danych o charakterze jakościowym oraz ilościowym. Podstawowym źródłem informacji były dane Głównego Urzędu Statystycznego (Bank Danych Lokalnych - BDL), które w przypadku analiz demograficznych, migracji i ryn$\mathrm{ku}$ mieszkaniowego stanowiły element badań podstawowych. Ponadto w niniejszym opracowaniu powołano się na badania demograficzne przeprowadzone dla aglomeracji poznańskiej w 2011 r. pod kierownictwem prof. dr. hab. Tomasza Kaczmarka w Centrum Badań Metropolitalnych Uniwersytetu im. Adama Mickiewicza w Poznaniu w związku z realizacją projektu o nazwie „Funkcjonowanie i kierunki rozwoju aglomeracji poznańskiej”.

\section{CHARAKTERYSTYKA DEMOGRAFICZNA AGLOMERACJI POZNAŃSKIEJ}

Aglomeracja poznańska jest siódmą co do wielkości aglomeracją w Polsce, którą zamieszkuje 0,9 mln osób (po aglomeracji górnośląskiej $3 \mathrm{mln}$, warszawskiej - 2,6 mln, łódzkiej - 1,1 mln, krakowskiej, wrocławskiej i trójmiejskiej - $1 \mathrm{mln}$ ). Poznań, miasto centralne aglomeracji, jest z kolei piątym co do wielkości miastem w Polce (po Warszawie, Krakowie, Łodzi i Wrocławiu).

W 2011 r. aglomerację poznańską zamieszkiwało 891447 osób, a gęstość zaludnienia wynosiła 412 os. $/ \mathrm{km}^{2}$. W Poznaniu w 2011 r. liczba mieszkańców wynosiła 553564 osoby, co stanowiło 62\% mieszkańców całej aglomeracji poznańskiej. Od 1990 r. widoczny jest spadek liczby mieszkańców miasta Poznania i wzrost liczby mieszkańców powiatu poznańskiego, a także powolny, ale systematyczny wzrost liczby ludności całej aglomeracji poznańskiej. Proces ten jest charakterystyczny dla aglomeracji miejskich $w$ całej Polsce i związany $\mathrm{z}$ procesem transformacji ustrojowej oraz intensywnej suburbanizacji strefy podmiejskiej.

Zmiany liczby ludności w aglomeracji poznańskiej w ostatnich latach są przestrzennie zróżnicowane. W latach 1990-2011 w Poznaniu odnotowano ubytek liczby ludności o 6\%. W latach 2000-2011 najwięcej osób opuściło śródmiejskie dzielnice Poznania (Stare Miasto - ubytek o 23\%, Jeżyce - ubytek o 17\%, Łazarz - ubytek o 16\%), chociaż negatywny trend „ucieczki z miasta" pojawił się również na osiedlach wielkopłytowych (Rataje - ubytek o 13\%, Chartowo - ubytek o 10\%). Pomimo ogólnej tendencji do przeprowadzek poza miasto w strukurze przestrzennej Poznania istnieją obszary, 


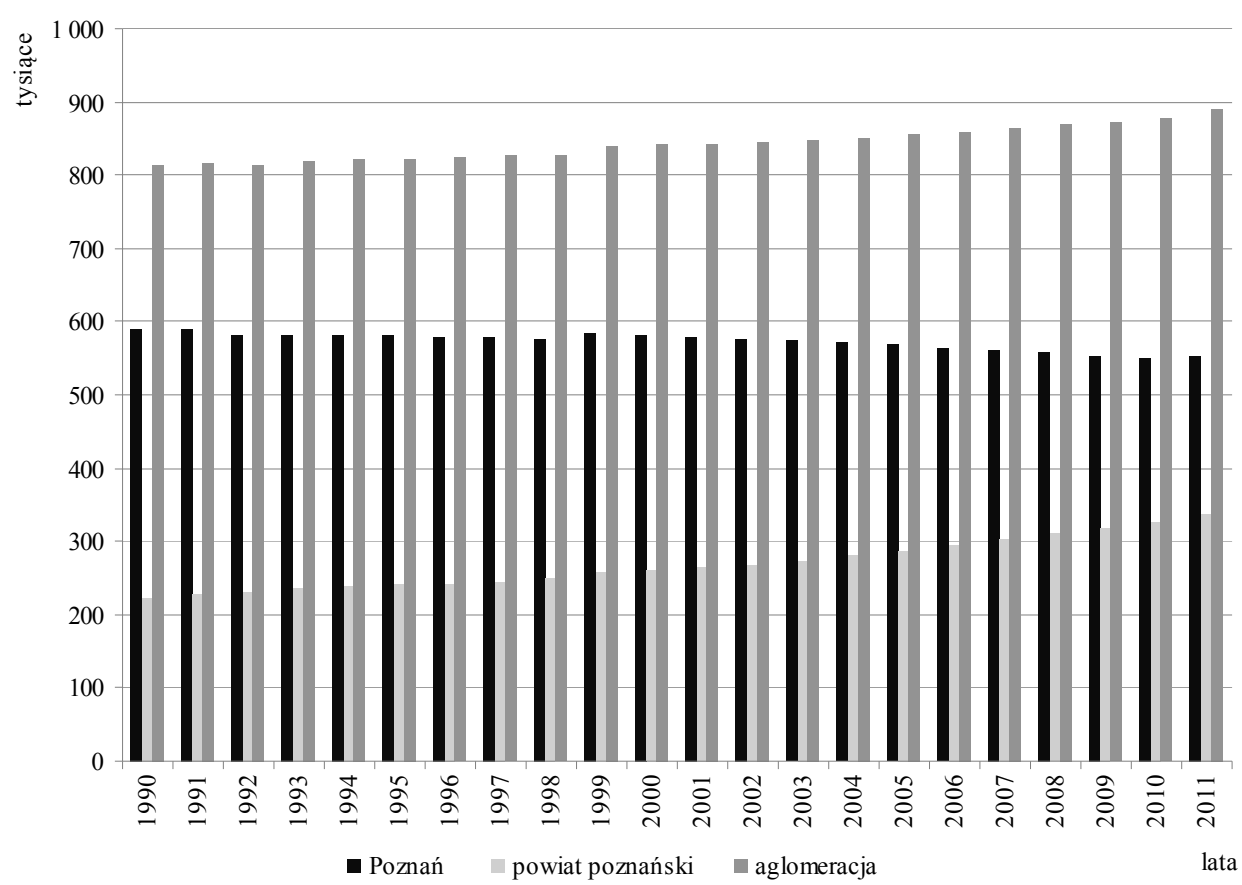

Rycina 1. Liczba ludności w aglomeracji poznańskiej w latach 1990-2011

Źródło: Opracowanie własne na podstawie BDL GUS.

na których $\mathrm{w}$ ostatnich latach intensywnie rozwijało się budownictwo mieszkaniowe. Atrakcyjność tych obszarów, wyższy standard mieszkań, bliskość terenów zieleni, a przede wszystkim lokalizacja stosunkowo blisko centrum spowodowały, że zanotowano tam wzrost liczby mieszkańców (Radojewo - wzrost o 69\%, Morasko - wzrost o 65\%, Naramowice - wzrost o $41 \%)$.

Poza obszarem Poznania, w jego strefie podmiejskiej, najszybszy wzrost zaludnienia w latach 1990-2011 wystąpił w gminie Dopiewo (124\%), Komorniki (107\%) i Rokietnica (102\%). W żadnej z gmin powiatu poznańskiego w tym okresie nie zanotowano ubytku liczby ludności.

Migracje poza Poznań oraz zmiany przyrostu naturalnego wpłynęły na strukturę biologiczną i społeczno-zawodową mieszkańców aglomeracji poznańskiej. Poza Poznań wyprowadzają się głównie osoby w wieku reprodukcyjnym, dlatego w obszarze podmiejskim obserwuje się znaczny wzrost udziału dzieci i młodzieży w ogólnej liczbie mieszkańców. 
Tabela. Liczba ludności i dynamika zmian w aglomeracji poznańskiej w latach 1990-2011

\begin{tabular}{|c|c|c|c|c|}
\hline \multirow{2}{*}{ Jednostka } & \multicolumn{3}{|c|}{ Liczba ludności } & \multirow{2}{*}{$\begin{array}{c}\text { Dynamika zmian } \\
\text { zaludnienia w latach } \\
\text { 1990-2011 (w \%) }\end{array}$} \\
\hline & 1990 & 2000 & 2011 & \\
\hline $\begin{array}{l}\text { Miasto } \\
\text { Poznań }\end{array}$ & 590101 & 566491 & 553564 & -6 \\
\hline Buk & 11145 & 11630 & 12297 & 10 \\
\hline Czerwonak & 14396 & 21335 & 26285 & 83 \\
\hline Dopiewo & 8670 & 10609 & 19391 & 124 \\
\hline Kleszczewo & 4103 & 4626 & 6384 & 56 \\
\hline Komorniki & 10089 & 11634 & 20890 & 107 \\
\hline Kostrzyn & 14616 & 15088 & 17242 & 18 \\
\hline Kórnik & 13833 & 14880 & 21495 & 55 \\
\hline Luboń & 20238 & 23391 & 30066 & 49 \\
\hline Mosina & 22516 & 23445 & 28515 & 27 \\
\hline $\begin{array}{l}\text { Murowana } \\
\text { Goślina }\end{array}$ & 12980 & 15100 & 16530 & 27 \\
\hline Pobiedziska & 13548 & 14901 & 18368 & 36 \\
\hline Puszczykowo & 8296 & 8549 & 9812 & 18 \\
\hline Rokietnica & 6583 & 7653 & 13294 & 102 \\
\hline Stęszew & 12474 & 13479 & 14600 & 17 \\
\hline Suchy Las & 7659 & 10015 & 15253 & 99 \\
\hline Swarzędz & 30794 & 36334 & 45160 & 47 \\
\hline $\begin{array}{l}\text { Tarnowo } \\
\text { Podgórne }\end{array}$ & 12754 & 16062 & 22301 & 75 \\
\hline $\begin{array}{l}\text { Powiat } \\
\text { poznański }\end{array}$ & 224694 & 258731 & 337883 & 50 \\
\hline $\begin{array}{l}\text { Aglomeracja } \\
\text { poznańska }\end{array}$ & 814795 & 825222 & 891447 & 9 \\
\hline
\end{tabular}

Źródło: Opracowanie własne na podstawie BDL GUS.

W gminach podmiejskich od $1990 \mathrm{r}$. występuje dodatni przyrost naturalny. W Poznaniu w latach 1990-2004 miał miejsce ujemny przyrost naturalny. Od 2007 r. poziom urodzeń przewyższa poziom zgonów, dając $w$ rezultacie dodatni przyrost naturalny, co z demograficznego punktu widzenia jest bardzo korzystną sytuacją. Po głębokim niżu demograficznym lat dziewięćdziesiątych XX wieku $\mathrm{w}$ ostatniej dekadzie $\mathrm{w}$ całej aglomeracji wzrasta nadwyżka liczby urodzeń nad liczbą zgonów. Pozytywne tendencje w przyroście naturalnym są konsekwencją zmian w strukturze ludności według płci i wieku, przejawiających się wchodzeniem $\mathrm{w}$ wiek matrymonialny roczników mikrowyżu demograficznego z początku lat osiemdziesiątych ubiegłego stulecia. 
W gminach wiejskich aglomeracji poznańskiej udział ludności młodej $\mathrm{w}$ populacji jest wyższy niż w Poznaniu. Wynika to $\mathrm{z}$ modelu rodziny na wsiach, charakteryzującego się większą liczbą dzieci. Do najmłodszej demograficznie gminy należy Kleszczewo, gdzie udział osób powyżej 65. roku życia stanowi tylko $8 \%$, podczas gdy udział dzieci i młodzieży jest wysoki i wynosi $21 \%$ ogółu mieszkańców gminy. W Poznaniu udział osób starszych wynosi 15\% i przewyższa już grupę dzieci i młodzieży (12\%).

Przedstawiona powyżej charakterystyka demograficzna aglomeracji poznańskiej pozwala na sformułowanie następujących wniosków:

- na obszarze aglomeracji poznańskiej zachodzą intensywne przemieszczenia ludności, które przebiegają głównie jednokierunkowo: z miasta Poznania do strefy podmiejskiej,

- dynamika zmian zaludnienia w strefie podmiejskiej w ostatnim dwudziestoleciu jest bardzo wysoka, w niektórych gminach w tym okresie doszło do podwojenia się liczby mieszkańców,

- migracje poza Poznań wpływają na zmiany struktury biologicznej mieszkańców, ponieważ poza Poznań wyprowadzają się głównie osoby młode $\mathrm{w}$ wieku reprodukcyjnym,

- migracje poza Poznań wpływają również na strukturę społeczno-zawodową ludności (rzetelna ocena tego aspektu będzie możliwa po opublikowaniu danych ze Spisu Ludności i Mieszkań z 2011 r.).

\section{GŁÓWNE PRZYCZYNY MIGRACJI W AGLOMERACJI POZNAŃSKIEJ}

Aglomeracja poznańska jest jednym z najdynamiczniej rozwijających się obszarów miejskich w kraju. Jej rozwój dokonuje się na trzech płaszczyznach: gospodarczej, społecznej i przestrzennej. Postęp gospodarczy mierzony jest wysokim poziomem PKB na jednego mieszkańca, dużym udziałem spółek z kapitałem zagranicznym, a także subiektywnym poczuciem poprawy warunków i komfortu życia mieszkańców aglomeracji. Rozwój demograficzny i społeczny aglomeracji to wzrost kapitału społecznego i ludzkiego aglomeracji, który opisują cechy ilościowe (wzrost liczby mieszkańców), jak i jakościowe (wysoce wykształcone społeczeństwo). Rozwój przestrzenny aglomeracji wyraża się poprzez powstawanie nowych terenów zabudowy mieszkaniowej, sportowo-rekreacyjnej czy handlowo-usługowej.

Wszystkie trzy wyżej wymienione aspekty dynamicznego rozwoju aglomeracji poznańskiej można uznać za przyczynę, ale także skutek migracji wewnętrznych. Przyjmując pewne uogólnienia, można stwierdzić, że: 
- rozwój gospodarczy strefy podmiejskiej, lokalizacja nowych firm głównie przy ważnych trasach drogowych (np. Kórnik, Suchy Las) przyczyniły się do stałych migracji mieszkańców w pobliże miejsca pracy,

- migracje mieszkańców, zwłaszcza ludzi młodych i wykształconych, spowodowały wzrost kapitału społecznego i odmłodzenie demograficzne $\mathrm{w}$ gminach podmiejskich,

- przestrzenny rozwój aglomeracji, głównie terenów mieszkaniowych, doprowadził do wykrystalizowania się nowej struktury funkcjonalno-przestrzennej aglomeracji poznańskiej, w której atrakcyjność pewnych obszarów wzrosła, a innych spadła (celem migracji stały się obszary, w ocenie migrantów, bardziej atrakcyjne).

Powyżej przedstawione w zarysie podstawowe czynniki wpływające na wzrost liczby osób przeprowadzających się poza Poznań należy traktować jedynie jako pewne ramy dla procesu suburbanizacji, którego eksplozja w postaci nagłego przyrostu zabudowy mieszkaniowej i usługowej nastąpiła około roku 2000. Specyficzny typ migracji wewnętrznych, zachodzących na obszarze aglomeracji z powodów mieszkaniowych, nosi nazwę migracji rezydencjalnych (szerzej o tym typie migracji na przykładzie aglomeracji poznańskiej piszą m.in. M. Beim i A. Tölle (2008)).

Migrantów rezydencjalnych charakteryzuje duża mobilność oraz większa $\mathrm{w}$ związku z tym skłonność do podejmowania codziennych migracji wahadłowych (dom-praca-dom, dom-szkoła-dom). Według M. Ouředníčka (2010) poziom migracji do strefy podmiejskiej zależy również od struktury społecznej i preferencji mieszkaniowych. W przypadku społeczeństwa bogatego, charakteryzującego się dużym udziałem dzieci i młodzieży, wyższa jest skłonność do przeprowadzek na obszar suburbanizujący się niż w przypadku społeczeństw mniej zamożnych.

Przyczyny migracji mieszkańców Poznania do strefy podmiejskiej zostały zbadane przez M. Beima (2007). Na podstawie przeprowadzonego badania ankietowego na próbie sześciuset osób stwierdzono, że głównymi motywami migracji poza Poznań są:

- nieodpowiednia powierzchnia dotychczasowego mieszkania i chęć jego zamiany na większe,

- zmiana sytuacji rodzinnej,

- poprawa sytuacji finansowej,

- wysoki poziom hałasu w poprzednim miejscu zamieszkania.

Autor przeprowadził również badania dotyczące czynników wpływających na wybór nowego miejsca zamieszkania. Najważniejszymi z nich dla osób migrujących poza Poznań są czynniki środowiskowe: cisza, bliskość terenów zieleni, czyste powietrze. $W$ dalszej kolejności respondenci zwrócili 
uwagę na możliwość zakupu mieszkania po korzystniejszej cenie. Na trzecim miejscu znalazła się dogodna możliwość dojazdu samochodem do Poznania.

Istotnym elementem badań przeprowadzonych przez M. Beima jest również ocena decyzji o zmianie miejsca zamieszkania. Ponad połowa osób $(56,8 \%)$, które przeprowadziły się poza Poznań, jest z tego zadowolona. Najwięcej osób cieszy się z poprawy warunków mieszkaniowych, polepszenia jakości środowiska oraz znacznej poprawy w dostępie do terenów zielonych.

Możliwość migracji poza Poznań zaistniała dzięki bardzo dynamicznemu rozwojowi terenów budownictwa mieszkaniowego w gminach podmiejskich, co łączyć należy ze zjawiskiem suburbanizacji. Suburbanizacja w aglomeracji poznańskiej często przybiera negatywną postać typu "greenfield", co oznacza wydawanie zezwoleń na powstanie zabudowy w obszarach często do tego nieprzystosowanych pod względem wyposażenia $w$ infrastrukturę techniczną, w tym drogową.

Obok budownictwa typu deweloperskiego, głównie wielorodzinnego, doszło w ostatnich latach do intensywnej sprzedaży gruntów przeznaczonych pod budownictwo jednorodzinne. Według B. Maćkiewicz (2008) wśród osób nabywających nieruchomości gruntowe w powiecie poznańskim w latach 1995-2000 przeważali mieszkańcy województwa wielkopolskiego (95\% nabywców). Spośród tej liczby najczęściej grunty w powiecie poznańskim kupowali mieszkańcy Poznania $(54,3 \%)$ oraz powiatu poznańskiego $(41,1 \%)$. Spośród gruntów zakupionych przez mieszkańców miasta Poznania dominowały nieruchomości niezabudowane o przeznaczeniu mieszkaniowym. Autorka podkreśla, że „w badanym okresie popyt na nieruchomości niezabudowane miał zdecydowanie lokalny charakter" (Maćkiewicz 2008: 147).

Jak wynika z badań przeprowadzonych przez B. Maćkiewicz (2011), intensywna sprzedaż gruntów niezabudowanych miała miejsce głównie w gminach wiejskich aglomeracji poznańskiej, przylegających do granic z miastem Poznaniem od strony zachodniej (Rokietnica, Tarnowo Podgórne, Dopiewo). W tych gminach $\mathrm{w}$ ostatnich latach doszło do dynamicznego procesu wyłączenia użytków rolnych z produkcji rolniczej (Głębocki, Kacprzak 2011).

Dla zobrazowania zintensyfikowanego ruchu budowlanego, który wystąpił na terenie powiatu poznańskiego, przeprowadzono analizę nowych mieszkań oddanych do użytkowania. Do 2007 r. podaż nowych mieszkań była zdecydowanie wyższa w Poznaniu niż w powiecie poznańskim. Wyjątkiem był rok 1992, kiedy liczba nowych mieszkań w powiecie poznańskim przekroczyła liczbę nowych mieszkań oddanych do użytku w Poznaniu 
(w tym okresie tylko w dwóch gminach: Swarzędz i Czerwonak, wybudowano ponad 1100 mieszkań). Po 2007 r. doszło do gwałtownego odwrócenia tego trendu. W 2011 r. w powiecie poznańskim oddano do użytkowania o 1812 mieszkań więcej niż w Poznaniu. Warto podkreślić, że w 2007 r. wystąpił szczyt migracji mieszkańców Poznania do strefy podmiejskiej, co chronologicznie niemalże pokrywa się $\mathrm{z}$ „boomem mieszkaniowym” $\mathrm{w}$ powiecie poznańskim (ryc. 2).

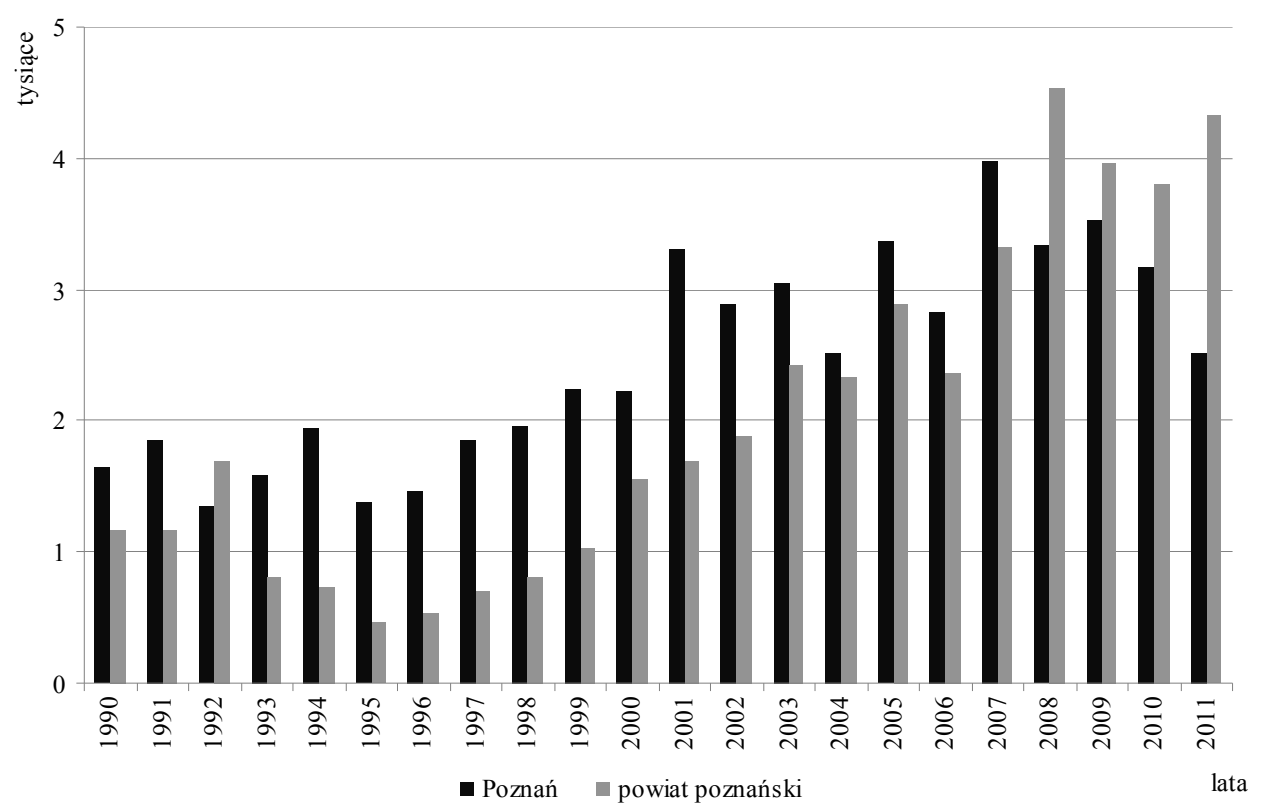

Rycina 2. Mieszkania oddane do użytkowania w aglomeracji poznańskiej w latach 1990-2011

Źródło: Opracowanie własne na podstawie BDL GUS.

Konsekewencją wzrostu liczby mieszkań w aglomeracji poznańskiej było zwiększenie powierzchni użytkowej mieszkań, co przełożyło się na poprawę warunków mieszkaniowych ludności aglomeracji. W 1990 r. przeciętna powierzchnia użytkowa mieszkania w Poznaniu na jednego mieszkańca wynosiła $18,5 \mathrm{~m}^{2}$. W gminach podpoznańskich powierzchnia ta była zróżnicowana (np. 18,5 $\mathrm{m}^{2} \mathrm{w}$ mieście Buk, 23,7 $\mathrm{m}^{2} \mathrm{w}$ Puszczykowie, 17,8 $\mathrm{m}^{2}$ w Czerwonaku). W 2002 r. na jednego mieszkańca powiatu poznańskiego przypadało już 25,5 m², a na jednego mieszkańca Poznania 23,1 m². W $2010 \mathrm{r}$. $\mathrm{w}$ powiecie poznańskim i w Poznaniu liczby te wynosiły odpowiednio: $29,3 \mathrm{~m}^{2}$ i $27,5 \mathrm{~m}^{2}$. Dynamika przyrostu powierzchni mieszkaniowej przypa- 
dającej na jednego mieszkańcach $w$ latach 2002-2010 była nieco wyższa w Poznaniu niż w powiecie poznańskim i wyniosła 19\% (w powiecie ok. $15 \%)$.

\section{PRZEBIEG PROCESÓW MIGRACYJNYCH W AGLOMERACJI POZNAŃSKIEJ W LATACH 1990-2011}

Według D. Jędrzejczyka (2001) migracje, zarówno zbiorowe, jak i indywidualne, są formą zaspokojenia potrzeb, których realizacja wymaga zmiany miejsca zamieszkania. Zmiana ta wynika $\mathrm{z}$ braku możliwości zaspokojenia potrzeb jednostki lub grupy $\mathrm{w}$ dotychczasowym miejscu zamieszkania, co często jest wynikiem wzrostu statusu ekonomicznego, oczekiwań i aspiracji życiowych.

Według A. Saksona (2008) ruchy migracyjne są efektem nie tylko obiektywnej analizy określonych czynników, ale raczej ich percepcji, przy czym dotychczasowe miejsce zamieszkania może zostać racjonalnie ocenione (jako bardziej znane), natomiast ocena miejsca migracji jest „nacechowana dużą niedoskonałością posiadanych informacji i obarczona dużą niepewnością". Jest to szczególnie znamienne dla migracji zagranicznych, a niepewność oceny nowego miejsca zamieszkania jest tym większa, im większą odległość ma pokonać migrant.

Niniejsze opracowanie odnosi się do skali migracji mieszkańców aglomeracji poznańskiej w podziale na migracje zagraniczne i wewnętrzne. Należy uznać, że dla rozwoju tejże aglomeracji jako ośrodka o kształtujących się cechach metropolii ważne są oba typy migracji. Z punktu widzenia konkurencyjności aglomeracji poznańskiej zwiększenie liczby imigrantów zagranicznych przyczynia się do upowszechniania kultury obcokrajowców (bogactwo kulturowe) oraz przekazywania informacji o aglomeracji przyjaciołom czy rodzinie migrantów, co można potraktować jako specyficzny element promocji miasta i jego otoczenia.

\subsection{Migracje zagraniczne}

Migracje zagraniczne $\mathrm{w}$ aglomeracji poznańskiej są relatywnie niewielkie i nie odgrywają znaczącej roli, jeśli chodzi o zmiany liczby ludności, co sprawia, że społeczeństwo tego regionu jest heterogeniczne pod względem narodowościowym i religijnym.

W 1990 r. z miasta Poznania za granicę wymeldowały się 222 osoby, do 2006 r. liczba ta wahała się dość znacznie między 100 a 200, osiągając najniż- 
sze wartości w latach 1999-2000 (ok. 50 osób) i 2001 (zaledwie 5 osób). Najwyższy szczyt migracji zagranicznych wystąpił w roku 2006 i trend ten dotyczył zarówno miasta Poznania, jak i powiatu poznańskiego. Z Poznania w 2006 r. wyemigrowało 515 osób.

W Poznaniu najwięcej obcokrajowców zameldowało się w latach 1992 i 2004 (ok. 170 osób), najmniej w 2001 r. (zaledwie 2 osoby). Większa liczba osób zameldowanych w 2004 r. ma zapewne związek z drugą falą reemigracji Polaków, która miała miejsce po wstapieniu do Unii Europejskiej (Fihel, Tyrowicz, Kaczmarczyk 2008). Od 2006 r. liczba osób emigrujących z Poznania jest wyższa niż imigrujących, saldo migracji zagranicznych jest więc ujemne.

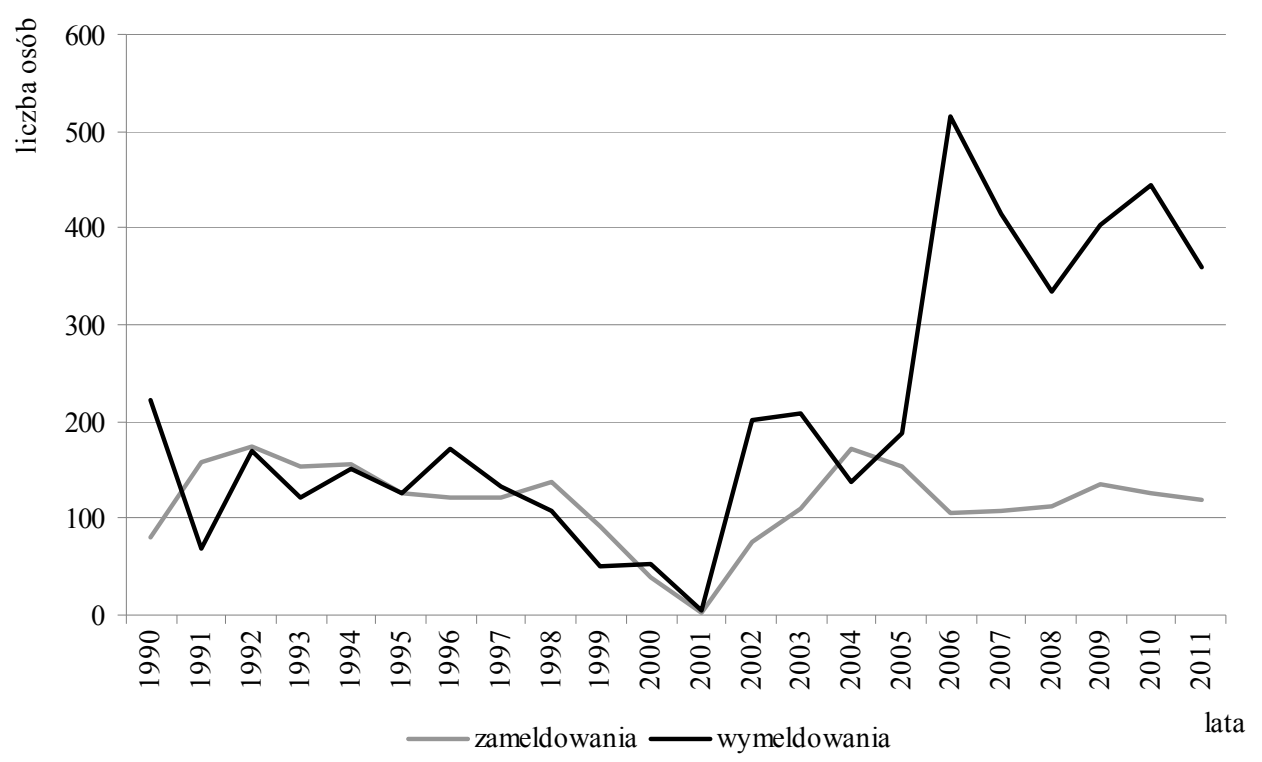

Rycina 3. Migracje zagraniczne w Poznaniu w latach 1990-2011

Źródło: Opracowanie własne na podstawie BDL GUS.

Powiat poznański staje się również nowym miejscem zamieszkania dla obcokrajowców. Największa liczba osób z zagranicy zameldowała się w powiecie poznańskim w 2009 r. (61 osób). Najwięcej osób wymeldowało się w 2006 r. (120 osób).

Migracje zagraniczne (zarówno imigracja, jak i emigracja) nie zachodzą w aglomeracji poznańskiej na dużą skalę. W mieście Poznań od 2000 r. saldo migracji zagranicznych jest stale ujemne (w latach 1990-2000 bywało zmienne), natomiast $w$ powiecie poznańskim saldo migracji zagranicznych od 
2005 r. jest ujemne (z wyjątkiem 2009 r.). Zachodzące zjawiska emigracji za granicę, choć typowe dla większości dużych miast polskich, pociągają za sobą negatywne skutki (odpływ wykwalifikowanej siły roboczej, rozerwanie więzi w rodzinach, z których przynajmniej jeden rodzic przebywa poza krajem, niższe podatki dla miast).

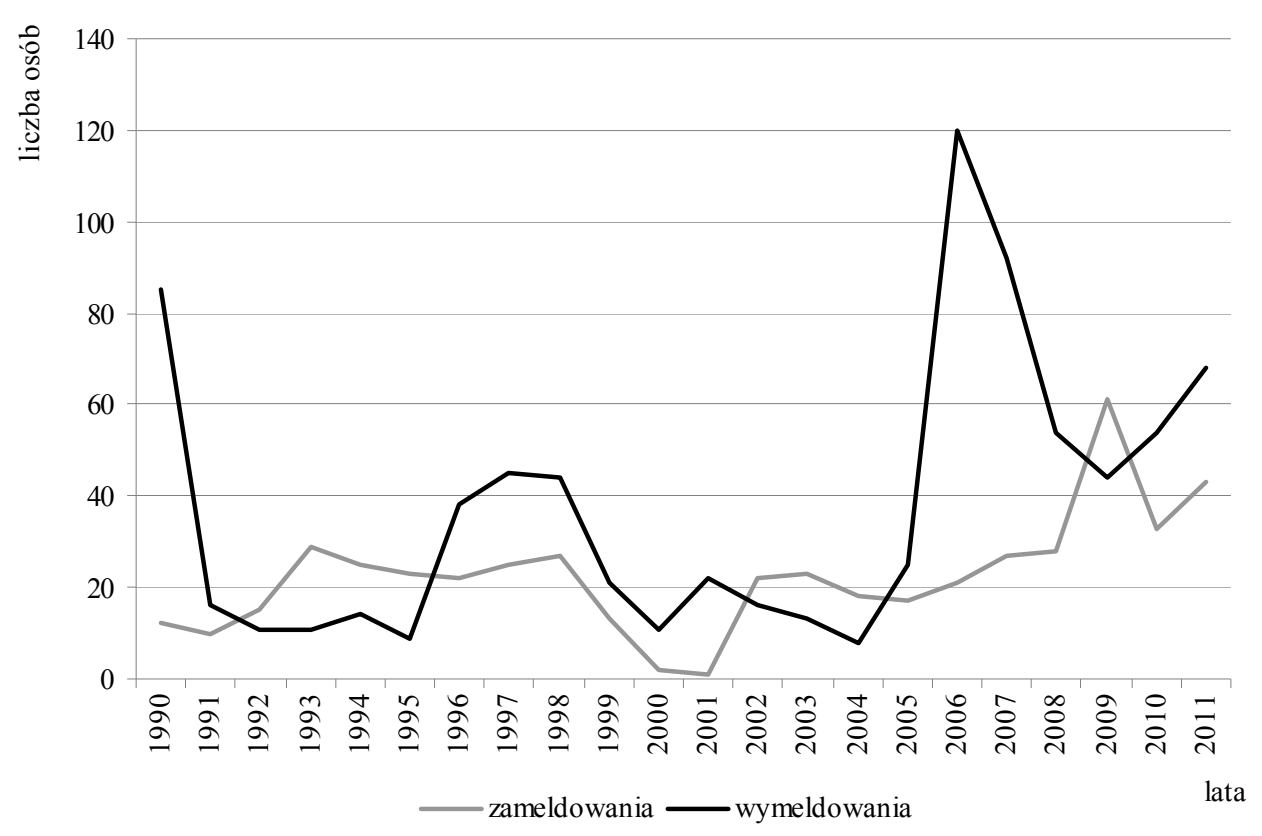

Rycina 4. Migracje zagraniczne w powiecie poznańskim w latach 1990-2011

Źródło: Opracowanie własne na podstawie BDL GUS.

\subsection{Migracje wewnętrzne}

W latach 1990-2000 saldo migracji wewnętrznych w Poznaniu ulegało zmianom, osiągając raz dodatnie, raz ujemne wartości. Od 2000 r. obserwuje się ujemne saldo migracji wewnętrznych, co należy wiązać z intensywnym odpływem mieszkańców poza jego granice administracyjne. W 2011 r. na 1000 mieszkańców miasta Poznania wymeldowało się 14 osób, podczas gdy w 1990 r. było to zaledwie 7 osób. W latach 1990-2011 współczynnik napływu wędrówkowego wahał się między 8 a 12 osobami na 1000 mieszkańców. Największy odpływ mieszkańców poza Poznań wystąpił w roku 2007, osiągając wartość 18 na 1000 mieszkańców. 


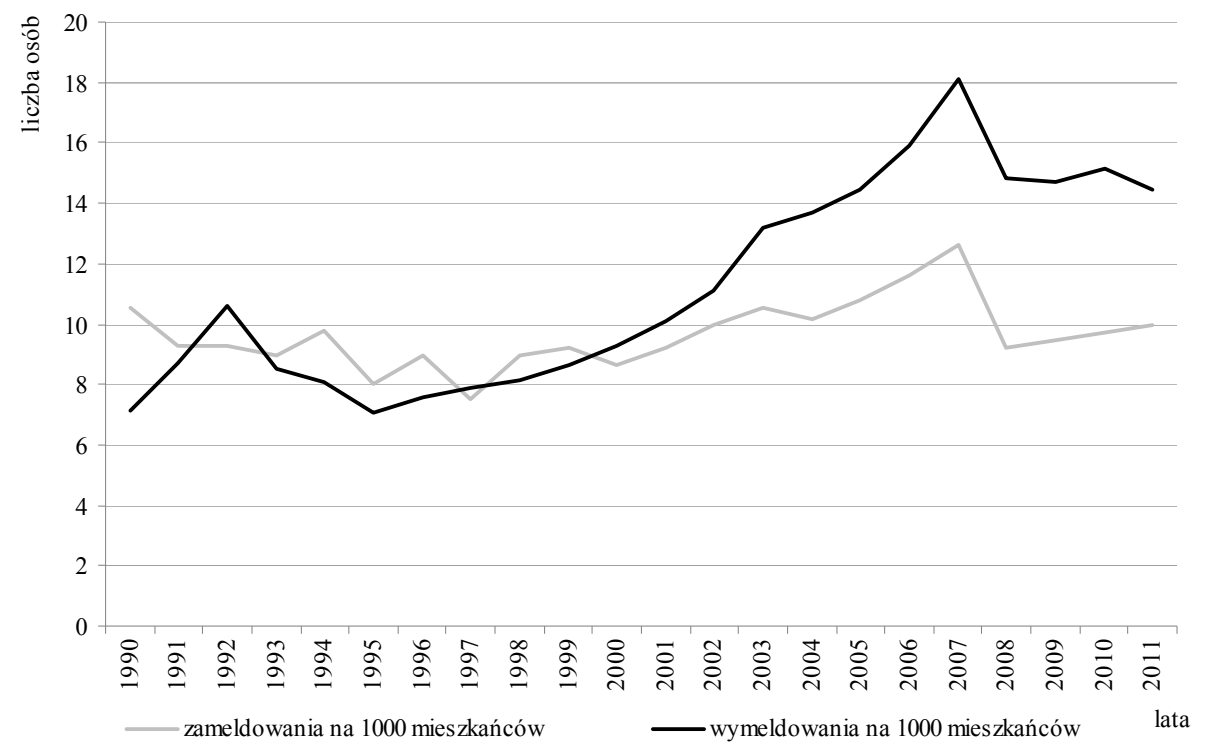

Rycina 5. Migracje wewnętrzne w Poznaniu w latach 1990-2011 Źródło: Opracowanie własne na podstawie BDL GUS.

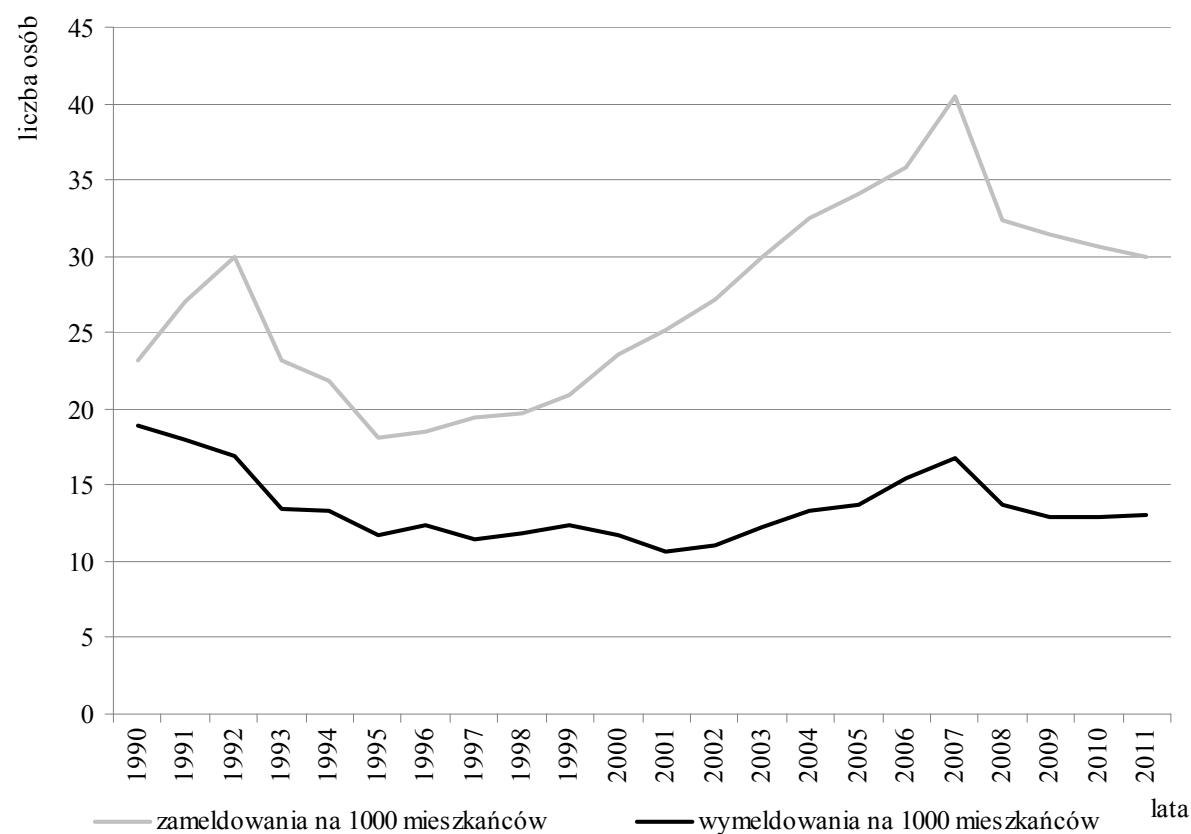

Rycina 6. Migracje wewnętrzne w powiecie poznańskim w latach 1990-2011 Źródło: Opracowanie własne na podstawie BDL GUS. 
W powiecie poznańskim migracje wewnętrzne (międzygminne) przedstawiąją się zupełnie inaczej niż w Poznaniu. W latach 1990-2011 w powiecie poznańskim zanotowano dodatnie saldo migracji, a więc nadwyżkę liczby osób zameldowanych nad wymeldowanymi. Najwyższy szczyt zameldowań w powiecie poznańskim wystąpił w roku 2007, osiągając wskaźnik 40 osób zameldowanych na 1000 mieszkańców. Warto zaznaczyć, że na ten sam rok przypadł również szczyt wyprowadzek mieszkańców miasta Poznania.

Migracje wewnętrzne $\mathrm{w}$ poszczególnych gminach powiatu poznańskiego zachodzą z różnym natężeniem, co prawdopodobnie oznacza, że niektóre z nich są bardziej atrakcyjne mieszkaniowo niż pozostałe. W 2011 r. najwięcej osób zameldowało się w gminach: Komorniki (1164 osób), Dopiewo (1098 osób), Swarzędz (1147 osób) oraz Mosina (941 osób), co może potwierdzać tezę, że głównym celem migracji mieszkańców są gminy położone w pierwszym pierścieniu okalającym miasto Poznań (dobra lokalizacja blisko miasta $\mathrm{z}$ możliwością szybkiego dotarcia indywidualnym środkiem transportu).

\section{WNIOSKI}

Na obszarze aglomeracji poznańskiej w ostatnich latach dochodzi do intensywnej suburbanizacji w jej najbardziej niekorzystnej postaci zwanej urban sprawl. Obszary silnie suburbanizujące się stanowily w ostatnich latach główny cel migracji rezydencjalnych mieszkańców Poznania.

Według J. Paryska (2008) faza rozwoju miasta zwana suburbanizacją jest bardzo widoczna w aglomeracji poznańskiej, a jej skutki przestrzenne i społeczno-ekonomiczne są szczególnie negatywne. Autor ten stwierdza, że suburbanizacja prowadzi przede wszystkim do: nieracjonalnego wykorzystania terenu, uszczuplenia terenów użytkowanych rolniczo i tzw. terenów otwartych, zwiększenia kosztów budowy sieci infrastruktury komunalnej oraz jej utrzymania, a także generowania ruchu drogowego o większym natężeniu (trudności komunikacyjne w obrębie miasta).

Dynamiczne zmiany w liczbie i rozmieszczeniu ludności na obszarze aglomeracji ( $\mathrm{w}$ ostatnim 20-leciu $\mathrm{w}$ niektórych gminach powiatu poznańskiego doszło do podwojenia się liczby mieszkańców) pociągnęły za sobą niekorzystne zjawiska z punktu widzenia zarządzania usługami publicznymi. Relatywnie duży wzrost liczby dzieci i młodzieży w gminach podmiejskich spowodował pilną potrzebę zwiększenia liczby miejsc w przedszkolach i szkołach. 
Według A. Lisowskiego i M. Grochowskiego (2010) popyt na tereny położone w różnych strefach obszaru metropolitalnego jest zmienny w czasie, podobnie jak realizowane tam inwestycje. Atrakcyjność obszarów i dzielnic mieszkaniowych nie jest więc cechą stałą, a kierunki migracji wewnętrznych w obszarach wielkomiejskich również się zmieniają. W zarządzaniu obszarami metropolitalnymi niezwykle ważne jest zatem prowadzenie rozważnej polityki planistycznej, uwzględniającej możliwe kierunki migracji mieszkańców i zmiany liczby ludności w przyszłości.

\section{BIBLIOGRAFIA}

Beim M. (2007), Modelowanie procesu suburbanizacji w aglomeracji poznańskiej z wykorzystaniem sztucznych sieci neuronowych i auotmatów komórkowych, rozprawa doktorska pisana pod kierunkiem prof. dr. hab. W. Ratajczaka na UAM w Poznaniu (niepubl.).

Beim M., Tölle A. (2008), Motywacje migracji rezydencjalnych w obszarze aglomeracji poznańskiej, [w:] Powiat poznański. Jakość przestrzeni i jakość życia, red. T. Kaczmarek, A. Mizgajski, Bogucki Wydawnictwo Naukowe, Poznań.

Fihel A., Tyrowicz J., Kaczmarczyk P. (2008), Migracje powrotne Polaków, Fundacja Inicjatyw Społeczno-Ekonomicznych, Biuletyn nr 5, Warszawa.

Głębocki B., Kacprzak E. (2011), Wyłączenia użytków rolnych z produkcji rolniczej, [w:] Studium uwarunkowań rozwoju przestrzennego aglomeracji poznańskiej, CBM UAM, Poznań.

Jędrzejczyk D. (2001), Podstawy geografii ludności, Wydawnictwo Akademickie Dialog, Warszawa.

Kaczmarek T. (2008), Aglomeracja poznańska jako region badania i działania, [w:] Powiat poznański. Jakość przestrzeni i jakość życia, red. T. Kaczmarek, A. Mizgajski, Bogucki Wydawnictwo Naukowe, Poznań.

Lisowski A., Grochowski M. (2010), Procesy suburbanizacji. Uwarunkowania, formy i konsekwencje, ekspertyza na potrzeby Koncepcji Przestrzennego Zagospodarowania Kraju, www.mir.gov.pl [dostęp: 22.042013].

Maćkiewicz B. (2008), Terytorialne pochodzenie nabywców nieruchomości niezabudowanych położonych w powiecie poznańskim, [w:] Powiat poznański. Jakość przestrzeni i jakość życia, red. T. Kaczmarek, A. Mizgajski, Bogucki Wydawnictwo Naukowe, Poznań.

Maćkiewicz B. (2011), Obrót nieruchomościami, [w:] Studium uwarunkowań rozwoju przestrzennego aglomeracji poznańskiej, CBM UAM, Poznań.

Ouředníček M. (2007), Differential suburban development in the Prague Urban Region, Geografiska Annaler: Series B, Human Geography.

Paelinck J.H.P., Klaassen J.H. (1979), Spatial Econometrics, Saxon House, Farnborough.

Parysek J. (2008), Aglomeracje miejskie w Polsce oraz problemy ich funkcjonowania i rozwoju, [w:] Wybrane problemy rozwoju i rewitalizacji miast: aspekty poznawcze i praktyczne, seria Rozwój Regionalny i Polityka Regionalna nr 5, Bogucki Wydawnictwo Naukowe, Poznań.

Sakson A. (2008), Migracje - fenomen XX i XXI wieku, „Przegląd Zachodni” 2008, nr 2. 